Penelitian

\title{
Potensi Ekstrak Kulit Pisang Kepok (Musa paradisiaca forma typica) dan Uli (Musa paradisiaca sapientum) Menaikkan Aktivitas Superoksida Dismutase dan Menurunkan Kadar Malondialdehid Organ Hati Tikus Model Hiperkolesterolemia
}

\section{The Potency of Kepok Banana peel Extract (Musa paradisiaca forma typica) and Uli (Musa paradisiaca sapientum) in Increasing Superoxide Dismutase Activity and Reducing Malondialdehyde Levels in the Liver of Hypercholesterolemic Rats Model}

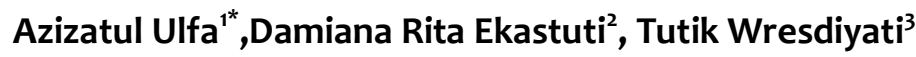 \\ ${ }^{1}$ Program Studi Ilmu-Ilmu Faal dan Khasiat Obat, Sekolah Pascasarjana, Institut Pertanian Bogor \\ ${ }^{2}$ Divisi Fisiologi, Departemen Anatomi, Fisiologi, dan Farmakologi, Institut Pertanian Bogor \\ ${ }^{3}$ Divisi Anatomi, Histologi, dan Embriologi, Departemen Anatomi, Fisiologi, dan Farmakologi, Institut Pertanian Bogor \\ *Penulis untuk korespondensi: azizatululfa@gmail.com \\ Diterima 14 Agustus 2019, Disetujui 22 Oktober 2019
}

\begin{abstract}
ABSTRAK
Penelitian ini bertujuan untuk menganalisis potensi antioksidan kulit pisang kepok dan kulit pisang uli pada hati tikus hiperkolesterolemia. Kulit pisang kepok dan uli diekstraksi dengan metode maserasi menggunakan pelarut air, etanol $70 \%$ dan etanol 96\%. Ekstrak diuji fitokimia secara kualitatif. Ekstrak diuji aktivitas antioksidanya menggunakan metode DPPH. Ekstrak dengan nilai $I C_{50}$ terendah dipilih untuk uji in vivo. Desain penelitian pada uji in vivo meliputi pencegahan dan pengobatan. Uji in vivo dilakukan dengan memberikan varian ekstrak kepada kelompok tikus percobaan. Parameter yang diamati adalah aktivitas SOD dan kadar MDA organ hati. Ekstrak kulit pisang kepok memiliki rendemen 17,97\% (pelarut air), 17,18\% (pelarut etanol 70\%) dan 15,02\% (pelarut etanol 96\%). Ekstrak kulit pisang uli memiliki rendemen 33,04\% (pelarut air), 27,2\% (pelarut etanol 70\%) dan 34,42\% (pelarut etanol 96\%). Ekstrak kulit pisang kepok dan uli pada berbagai pelarut memiliki karakteristik warna coklat. Semua ekstrak mengandung senyawa flavonoid. Saponin terdapat pada semua ekstrak kecuali ekstrak kulit pisang uli dengan pelarut etanol 96\%. Triterpenoid hanya terkandung pada ekstrak kulit pisang kepok dengan pelarut etanol. Ekstrak kulit pisang kepok dengan pelarut etanol $70 \%$ memiliki nilai $I C_{50}$ terendah $(P<0.01)$ dibandingkan dengan jenis ekstrak lainnya. Kelompok pencegahan dan kelompok pengobatan yang dicekok ekstrak etanol 70\% kulit pisang kepok memiliki aktivitas SOD secara nyata lebih tinggi dan kadar MDA lebih rendah dibandingkan kelompok yang tidak dicekok ekstrak $(\mathrm{P}<0,05)$. Ekstrak kulit pisang kepok dengan pelarut etanol $70 \%$ menunjukkan aktivitas antioksidan yang paling baik. Ekstrak etanol 70\% kulit pisang kepok menaikkan aktivitas superoksida dismutase dan menurunkan kadar malondialdehid organ hati tikus percobaan model hiperkolesterolemia baik sebagai pencegahan maupun pengobatan.
\end{abstract}

Kata kunci: antioksidan, kulit pisang kepok, kulit pisang uli, MDA, SOD

\begin{abstract}
The objectives of this study were to observe the antioxidant potency of kepok and uli banana peel extract. Kepok and Uli banana peels were extracted by maceration method using water, 70\% ethanol and 96\% ethanol solvent. Extracts were tested qualitatively by phytochemicals. Extracts were tested for antioxidant activity using the DPPH method. The extract with the lowest $I C_{50}$ value was chosen for the in vivo test. The research design in the in vivo test includes prevention and treatment. In vivo tests were carried out by giving extract variants to groups of experimental rats. The parameters observed were SOD activity and MDA levels in the liver. Kepok banana peel extracts have a yield of $17.97 \%$ (water solvent), $17.18 \%$ ( $70 \%$ ethanol solvent) and $15.02 \%$ ( $96 \%$ ethanol solvent). Uli banana peel extracts have a yield of $33.04 \%$ (water solvent), $27.2 \%$ (70\% ethanol solvent) and $34.42 \%$ ( $96 \%$ ethanol solvent). Kepok and uli banana peel extract in various solvents have the characteristics of brown color. All extracts contain flavonoids. Saponins were found in all extracts except uli banana peel extract with ethanol $96 \%$ solvent. Triterpenoids were only contained in kepok banana peel extract with ethanol solvent. Kepok banana peel extract with ethanol $70 \%$ solvent had a lowest $I C_{50}$ value $(\mathrm{P}<0.01)$ compared to the other extracts. The groups that were treated with $70 \%$ ethanol extract of kepok banana peel has higher SOD activity and lower MDA levels than untreated group $(P<0,05)$ both on the preventive and treatment group. Kepok banana peel extract with ethanol 70\% solvent showed the best antioxidant activity. The 70\% ethanol extract of kepok banana peel increased the activity of superoxide dismutase and reduced malondialdehyde levels in the liver of hypercholesterolemic rat model as a preventive and treatment.
\end{abstract}

Keywords: antioxidant, kepok banana peel, MDA, SOD, uli banana peel 


\section{PENDAHULUAN}

Hiperkolesterolemia merupakan gangguan metabolisme yang ditandai dengan peningkatan kadar total kolesterol dalam darah (Csonka et al. 2016). Hiperkolesterolemia diikuti oleh peningkatan kadar Low Density Lipoprotein (LDL) yang tidak terkendali. Kondisi ini menyebabkan aterosklerosis, penyakit jantung koroner serta penyakit degeneratif yang lain (Yani 2015). LDL mengandung kolesterol paling banyak dengan konsentrasi kolesterol plasma total sebanyak $70 \%$. Kolesterol LDL akan dibawa ke hati dan jaringan steroidogenik yang memiliki reseptor kolesterol LDL. Sebagian kolesterol LDL menuju ke subendotel dan mengalami oksidasi. Banyaknya oksidasi berbanding lurus dengan kolesterol LDL yang terdapat dalam plasma (Jim 2013). Oksidasi lipoprotein LDL menghasilkan radikal bebas (Wresdiyati et al. 2006). Csonka et al. (2016) melaporkan bahwa radikal bebas dapat diatasi oleh antioksidan endogen maupun eksogen.

Antioksidan merupakan senyawa yang dapat menyeimbangkan jumlah oksidan di dalam tubuh. Efektivitas antioksidan sebanding dengan jumlah gugus hidroksil $(\mathrm{OH})$ yang ada dalam cincin aromatiknya (White et al. 2014). Antioksidan didefinisikan sebagai senyawa yang dapat menunda atau menghambat oksidasi. Antioksidan berperan untuk mencegah kerusakan komponen seluler yang timbul akibat dari stress oksidatif. Antoksidan melindungi sel dari radikal bebas dengan cara pemecahan rantai oksidan, mengikat ikatan logam dan reaksi antioksidan enzim (Young dan Woodside 2001).

Kulit pisang merupakan limbah dari buah pisang yang memiliki banyak manfaat. Enein et al. (2016) melaporkan kulit pisang mengandung beberapa unsur penting yang dibutuhkan oleh tubuh diantaranya karbohidrat, magnesium, protein, kalsium, fosfor, zat besi, natrium, dan flavonoid. Senyawa bioaktif yang ada di dalam kulit pisang dapat dimanfaatkan sebagai antioksidan. Wardati (2017) melaporkan bahwa nilai $I C_{50}$ kulit pisang kepok yang diekstraksi menggunakan pelarut etanol $95 \%$ sebesar $220,375 \mu \mathrm{g} / \mathrm{mL}$ yang tergolong dalam aktivitas antioksidan sedang. Penelitian ini bertujuan untuk menganalisis karakteristik dan kandungan fitokimia ekstrak kulit pisang kepok dan uli, menganalisis aktivitas antioksidan ekstrak kulit pisang kepok dan uli serta menganalisis aktivitas superoksida dismutase dan kadar malondialdehid organ hati tikus tikus model hiperkolesterolemia.

\section{BAHAN DAN METODE}

\section{Bahan}

Bahan-bahan yang digunakan dalam penelitian ini adalah kulit pisang kepok matang yang diambil di daerah Sleman-Yogyakarta, kulit pisang uli matang yang diambil dari Kabupaten Bogor-Jawa Barat, air, etanol 70\%, etanol 96\%, akuades, larutan buffer asetat, trolox, quarsetin, asam galat, eter, $\mathrm{HCl}$, amil alkohol, serbuk $\mathrm{Mg}$, kloroform, amoniak, $\mathrm{H}_{2} \mathrm{SO}_{4}$, $\mathrm{FeCl}_{3}$, pereaksi Meyer, pereaksi Wagner, pereaksi Dragendorf, pereaksi Lieberman buchard, Buffer kalium fosfat, NADPH, Difenilpikril Hidrazil Hidrat (DPPH) merk Sigma, bubuk kolesterol, Rotary evaporator Heidolph, dan tikus putih galur Sprague Dawley.

\section{Ekstraksi (Nugroho et al. 2016)}

Ekstraksi kulit buah pisang kepok dan uli dilakukan dengan metode maserasi. Sampel masingmasing diekstraksi dengan air, etanol 70\% dan etanol 96\% dengan perbandingan jumlah pelarut dan sampel 10:1. Sampel diletakkan pada shaker incubator selama 24 jam pada suhu ruang. Filtrat diekstrak kembali sebanyak 2 kali masing-masing menggunakan jumlah pelarut yang sama dengan maserasi awal. Filtrat yang diperoleh dipekatkan dengan rotary evaporator pada suhu $50^{\circ} \mathrm{C}$ sehingga dihasilkan ekstrak kental.

\section{Uji Fitokimia (Hasanah et al. 2016)}

Uji fitokimia dilakukan pada setiap ekstrak meliputi identifikasi tanin, alkaloid, flavonoid, saponin, triterpenoid dan steroid. Uji fitokimia dilakukan secara kualitatif.

\section{Uji Aktivitas Antioksidan (Fatemeh et al. 2012)}

Uji aktivitas antioksidan menggunakan metode DPPH. Sampel ekstrak diambil sebanyak $1000 \mu \mathrm{L}$ dengan menambahkan $4 \mathrm{~mL}$ larutan metanol 0,1 $\mathrm{mM}$. DPPH ditambahkan ke tabung reaksi dan dikocok kuat. Tabung diinkubasi di ruang gelap pada suhu kamar selama 20 menit. Sampel kontrol disiapkan tanpa menggunakan penambahan ekstrak. Perubahan adsorbansi sampel diukur pada $517 \mathrm{~nm}$. Aktivitas antioksidan dihitung menggunakan rumus:

Radical scavenging activity $(100 \%)=(($ kontrol OD (optical density) - sampel OD)/kontrol OD) $\times 100$

Ekstrak yang menunjukkan aktivitas antioksidan terbaik digunakan pada uji in vivo. 


\section{Uji In Vivo (Pontang et al. 2014; Choundary 2013)}

Hewan percobaan adalah 28 tikus putih (Rattus novergicus strain Sprague dawley) jantan dengan umur 2 bulan. Hewan diaklimatisasi selama 1 minggu. Tikus dibagi menjadi 4 kelompok sama banyak. Dua kelompok tikus digunakan dalam desain kelompok pencegahan dan 2 kelompok lainnya digunakan dalam kelompok pengobatan. Ekstrak yang digunakan pada uji in vivo adalah ekstrak kulit pisang kepok dengan pelarut etanol 70\% (memiliki aktivitas antioksidan paling tinggi dari hasil pengujian in vitro) dengan dosis 200 $\mathrm{mg} / \mathrm{kgBB}$. Kelompok tikus pencegahan terdiri dari 1 kelompok yang diberikan diet kolesterol 1\% dan cekok aquades selama 28 hari (kode $\mathrm{Ch}$ ) dan 1 kelompok yang diberikan diet kolesterol $1 \%$ dan cekok ekstrak secara bersamaan selama 28 hari (Kode ChE). Kelompok tikus pengobatan terdiri dari 1 kelompok tikus yang diberi diet kolesterol $1 \%$ selama 28 hari sehingga mencapai kondisi hiperkolesterolemia kemudian dilanjutkan dengan ransum standar dan cekok aquades selama 28 hari (kode $\mathrm{Ch}+\mathrm{S}$ ) dan 1 kelompok yang diberi diet kolesterol $1 \%$ selama 28 hari sehingga mencapai kondisi hiperkolesterolemia kemudian diberikan ransum standar dan cekok ekstrak selama 28 hari (kode $\mathrm{Ch}+\mathrm{SE}$ ).

Pemeriksaan Profil Superoksida Dismutase (SOD) (Maskar et al. 2015) dan Malondialdehida (MDA) (Suarsana et al. 2013)

Pemeriksaan SOD dilakukan dengan mengambil $150 \mu \mathrm{L}$ supernatan organ hati yang telah di sentrifuge ke dalam $400 \mu \mathrm{L}$ kloroform $(37,5: 62,5 \mathrm{v} / \mathrm{v})$ pada kecepatan $4000 \mathrm{rpm}$ selama 10 menit. Lima puluh mikroliter supernatan ditambahkan ke dalam 2,9 ml larutan campuran xantin dan sitokrom $C$ (perbandingan 1:10) kemudian divorteks. Nilai adsorbansinya diukur menggunakan spektrofotometer pada panjang gelombang $550 \mathrm{~nm}$. MDA diukur dengan mencacah organ hati pada kondisi dingin. Homogenat disentrifuge dengan kecepatan $4000 \mathrm{rpm}$ selama 10 menit. Satu milliliter supernatan jernih diambil dan ditambahkan $\mathrm{HCl}$ dingin yang mengandung 0,38\% TBA (thiobarbituric acid), 15\% thricloroacetic dan 0,5\% BHT (butil hidorksitoluen). Campuran dipanaskan pada suhu $800 \mathrm{C}$ selama 1 jam kemudian disentrifuge pada kecepatan 3000rpm selama 10 menit. Adsorbansi diukur menggunakan spektrofotometer pada $532 \mathrm{~nm}$.

\section{Rancangan Percobaan dan Analisa Data (Steel dan Torrie 1980)}

Hasil penelitian dianalisis menggunakan program SPSS.22. Hasil pengukuran daya hambat antioksidan dianalisis Sidik Ragam Anova, apabila perlakuan memberikan pengaruh sangat nyata $(p<0,01)$ maka dilanjutkan uji lanjut Duncan. Hasil uji Aktivitas SOD dan kadar MDA dianalisis menggunakan Independent T-Test.

\section{HASIL}

Hasil karakteristik dan kandungan fitokimia ekstrak kulit pisang kepok dan uli disajikan dalam Tabel 1. Ekstrak kulit pisang kepok pada semua pelarut memiliki kadar air 6\% sedangkan pada ekstrak kulit pisang uli memiliki kadar air 4\%. Rendemen ekstrak kulit pisang kepok dengan pelarut air, etanol $70 \%$, dan etanol $96 \%$ secara berurutan adalah 17,97\%, 17,18\%, dan 15,02\%. Sedangkan pada rendemen ekstrak kulit pisang uli dengan pelarut air, etanol 70\%, dan etanol $96 \%$ secara berurutan sebesar 33,04\%, 27,2\%, dan 32,42\%. Ekstak kulit pisang kepok dan uli dengan berbagai jenis pelarut yang digunakan memiliki warna coklat.

Ekstrak kulit pisang kepok dengan pelarut etanol $70 \%$ dan etanol $96 \%$ mengandung senyawa flavonoid, saponin dan triterpenoid. Ekstrak kulit pisang kepok dengan pelarut air serta ekstrak kulit pisang uli dengan pelarut air dan etanol $70 \%$ juga mengandung senyawa flavonoid dan saponin, sedangkan triterpenoid tidak terkandung pada ketiga jenis ekstrak ini. Ekstrak kulit pisang uli dengan pelarut etanol $96 \%$ hanya mengandung senyawa flavonoid, sedangkan saponin dan triterpenoid tidak terkandung dalam senyawa ini. Ekstrak kulit pisang kepok dan uli dengan semua jenis pelarut tidak mengandung senyawa alkaloid, tannin, quinon, dan steroid.

Hasil uji aktivitas antioksidan disajikan dalam Tabel 2. Aktivitas antioksidan ekstrak kulit pisang kepok dengan pelarut etanol 70\% (IC $50128.46+$ $2.06 \mu \mathrm{g} / \mathrm{mL})$ dan etanol 96\% (IC $50137.78+$ $7.28 \mu \mathrm{g} / \mathrm{mL})$ secara sangat nyata $(P<0,01)$ lebih tinggi dibandingkan dengan ke-empat jenis ekstrak lainnya. Dari ke-enam sampel yang diujikan, ekstrak kulit pisang uli dengan pelarut etanol $96 \%$ memiliki aktivitas antioksidan paling rendah dengan

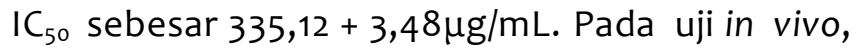


Tabel 1 Karakteristik dan kandungan fitokimia ekstrak kulit pisang kepok dan uli

\begin{tabular}{|c|c|c|c|c|c|c|c|}
\hline \multirow[b]{2}{*}{ Parameter } & & \multicolumn{3}{|c|}{ Kulit pisang kepok } & \multicolumn{3}{|c|}{ Kulit pisang uli } \\
\hline & & air & $\begin{array}{c}\text { Etanol } \\
70 \%\end{array}$ & $\begin{array}{c}\text { Etanol } \\
96 \%\end{array}$ & air & $\begin{array}{c}\text { Etanol } \\
70 \%\end{array}$ & $\begin{array}{c}\text { Etanol } \\
96 \%\end{array}$ \\
\hline Rendemen & & $17,97 \%$ & $17,18 \%$ & $15,02 \%$ & $33,04 \%$ & $27,2 \%$ & $34,42 \%$ \\
\hline Warna & & coklat & Coklat & coklat & coklat & coklat & coklat \\
\hline \multirow[t]{3}{*}{ Alkaloid: } & Wagner & - & - & - & - & - & - \\
\hline & Mayer & - & - & - & - & - & - \\
\hline & Dragendorf & - & - & - & - & - & - \\
\hline Flavonoid & & + & + & + & + & + & + \\
\hline Tanin & & - & - & - & - & - & - \\
\hline Saponin & & + & + & + & + & + & - \\
\hline Quinon & & - & - & - & - & - & - \\
\hline Triterpenoid & & - & + & + & - & - & - \\
\hline Steroid & & - & - & - & - & - & - \\
\hline
\end{tabular}

Keterangan: $(-)$ = mengandung senyawa, $(+)$ = tidak mengandung senyawa

dipilih ekstrak kulit pisang kepok dengan pelarut etanol $70 \%$ dikarenakan menunjukkan aktivitas antioksidan terbaik.

Hasil pengukuran aktivitas SOD dan kadar MDA organ hati tikus disajikan dalam Tabel 3. Pada kelompok pencegahan uji in vivo, aktivitas enzim antioksidan superoksida dismutase (SOD) organ hati pada kelompok tikus yang diberikan diet kolesterol $1 \%$ dan dicekok ekstrak kulit pisang kepok secara bersamaan selama 28 hari (aktivitas SOD 1946,66 + $23,56)$ secara nyata lebih tinggi $(P<0,05)$ dibandingkan dengan aktivitas antioksidan SOD kelompok yang hanya diberikan diet kolesterol $1 \%$ selama 28 hari tanpa dicekok ekstrak kulit pisang kepok (aktivitas SOD $1663+0$ ). Kadar MDA organ hati pada kelompok tikus yang diberikan diet kolesterol $1 \%$ dan dicekok ekstrak kulit pisang kepok secara bersamaan selama 28 hari (kadar MDA 0,159 + 0,152) secara nyata lebih rendah $(P<0,05)$ dibandingkan dengan kadar MDA kelompok yang hanya diberikan diet kolesterol $1 \%$ selama 28 hari tanpa dicekok ekstrak kulit pisang kepok (kadar MDA 2,293 + 0,512) (Tabel 3).

Pada kelompok pengobatan uji in vivo, aktivitas antioksidan SOD organ hati pada kelompok tikus hiperkolesterolemia yang hanya diberikan ransum standar selama 28 hari (aktivitas SOD 1097,074 + $93,074)$ secara sangat nyata lebih rendah $(P<0,01)$ dibandingkan dengan aktivitas antioksidan SOD kelompok hiperkolesterolemia yang diberikan diet ransum standar dan dicekok ekstrak kulit pisang kepok selama 28 hari (aktivitas SOD 1717,037 + 25,727). Kadar MDA organ hati pada kelompok tikus hiperkolesterolemia yang diberikan diet ransum standar selama 28 hari (kadar MDA $8,7+1,51$ ) secara sangat nyata lebih tinggi $(P<0,01)$ dibandingkan dengan kadar MDA kelompok hiperkolesterolemia yang diberikan diet ransum standar dan cekok ekstrak kulit pisang kepok selama 28 hari (kadar MDA 4,23+0,62). 
Tabel 2 Aktivitas antioksidan ( $\mathrm{IC}_{50}$ ) ekstrak kulit pisang kepok dan uli

\begin{tabular}{cll}
\hline Sampel & Pelarut & $\mathrm{IC}_{50}(\mu \mathrm{g} / \mathrm{ml})$ \\
\hline Ekstrak kulit pisang kepok & Air & $204.76 \pm 0.39^{\mathrm{b}}$ \\
& Etanol 70\% & $128.46 \pm 2.06^{\mathrm{a}}$ \\
Ekstrak kulit pisang uli & Etanol 96\% & $137.78 \pm 7.28^{\mathrm{a}}$ \\
& Air & $225.43 \pm 6.18^{\mathrm{c}}$ \\
& Etanol 70\% & $253.95 \pm 17.55^{\mathrm{d}}$ \\
& Etanol 96\% & $335.12 \pm 3.48^{\mathrm{e}}$ \\
\hline
\end{tabular}

Tabel 3 Hasil pengukuran aktivitas SOD dan kadar MDA organ hati tikus percobaan

\begin{tabular}{|c|c|c|}
\hline \multirow{2}{*}{ Parameter } & \multicolumn{2}{|c|}{ Kelompok pencegahan } \\
\hline & $\mathrm{Ch}$ & ChE \\
\hline SOD (U/g) & $1663 \pm 0^{a}$ & $1946.66 \pm 23.569^{b}$ \\
\hline \multirow[t]{3}{*}{ MDA ( $\mu \mathrm{g} / \mathrm{g}$ sampel) } & $2,923 \pm 0.512^{b}$ & $0.159 \pm 0.152^{a^{a}}$ \\
\hline & \multicolumn{2}{|c|}{ Kelompok pengobatan } \\
\hline & $\mathrm{Ch}+\mathrm{S}$ & $\mathrm{Ch}+\mathrm{SE}$ \\
\hline SOD (U/g) & $1097.074 \pm 93.704^{a}$ & $1717.037 \pm 25.727^{b}$ \\
\hline MDA ( $\mu \mathrm{g} / \mathrm{g}$ sampel) & $8.7 \pm 1,51^{b}$ & $4.23 \pm 0.62^{a}$ \\
\hline \multicolumn{3}{|c|}{$\begin{array}{l}\text { Ch= kelompok tikus yang diberi diet kolesterol } 1 \% \text { dan dicekok aquades selama } 28 \text { hari, ChE= kelompok tikus yang } \\
\text { diberi diet kolesterol } 1 \% \text { dan dicekok ekstrak } 200 \mathrm{mg} / \mathrm{KgBB} \text { selama } 28 \text { hari, } \mathrm{Ch}+\mathrm{S}=\text { kelompok tikus yang diberi diet ko- } \\
\text { lesterol } 1 \% \text { selama } 28 \text { hari dilanjutkan ransum standar dan dicekok aquades selama } 28 \text { hari, Ch+SE=kelompok tikus } \\
\text { yang diberi diet kolesterol } 1 \% \text { selama } 28 \text { hari dilanjutkan ransum standar dan cekok ekstrak 20omg/KgBB selama } 28 \\
\text { hari }\end{array}$} \\
\hline
\end{tabular}

\section{PEMBAHASAN}

Berdasarkan uji fitokimia yang telah dilakukan, kulit pisang kepok mengandung senyawa flavonoid, saponin dan triterpenoid. Jenis senyawa bioaktif kulit pisang kepok yang dilarutkan menggunakan pelarut etanol teridentifikasi lebih banyak (flavonoid, saponin, dan triterpenoid) dibandingkan dengan pelarut air (flavonoid dan saponin). Pada jenis kulit pisang uli, jenis bioaktif lebih banyak ditemukan pada ekstrak dengan pelarut air dan etanol $70 \%$ (flavonoid dan saponin) dibandingkan dengan pelarut etanol 96\% (flavonoid). Hal tersebut mengindikasikan bahwa senyawa bioaktif yang terdapat pada kulit pisang kepok cenderung larut pada senyawa semipolar sedangkan pada kulit pisang uli cenderung lebih polar. Flavonoid merupakan senyawa antioksidan yang terdapat pada semua jenis ekstrak kulit pisang dengan berbagai pelarut, akan tetapi flavonoid yang terkandung dalam ekstrak dengan pelarut etanol diduga memiliki kandungan flavonoid dengan jumlah yang lebih banyak dibandingkan dengan pelarut air. Indeks polaritas pelarut etanol menyebabkan etanol lebih efektif dibandingkan dengan pelarut air dalam menarik senyawa flavonoid (Widyawati et al. 2014).

Aktivitas antioksidan ekstrak kulit pisang kepok dengan pelarut etanol $(128,46+2,06$ dan 137,78 + $7,28)$ berbeda sangat nyata lebih tinggi $(P<0,01)$ dibandingkan dengan ke-empat jenis ekstrak lainnya (Tabel 2). Tingginya nilai aktivitas antioksidan pada ekstrak etanol $70 \%$ kulit pisang kepok diduga karena mengandung flavonoid paling banyak jumlahnya. Flavonoid dari tanaman berperan sebagai antioksidan karena cincin aromatiknya memiliki gugus hidroksil $(\mathrm{OH})$ bebas yang dapat menyumbangkan atom hidrogennya untuk berpasangan dengan radikal bebas (Sayuti dan Yenrina 2015). Jumlah gugus hidroksil yang berada dalam cincin aromatik sebanding dengan efektivitas antioksidan zat tersebut (White et al. 2014).

Konsumsi kolesterol pada kelompok tikus mengakibatkan jumlah LDL dalam plasma darah meningkat (Silverthorn 2002). LDL merupakan lipoprotein yang sangat mudah teroksidasi. Oksidasi tersebut memiliki hasil samping radikal bebas (Wresdiyati et al., 2006). Kandungan radikal bebas intraseluler dapat meningkat karena kelebihan produksi atau kurang pemusnahannya (Santoso 2017). Penambahan kolesterol secara terus menerus dalam kelompok tikus mengakibatkan kadar LDL plasma semakin meningkat sehingga radikal bebas yang diproduksi semakin banyak. SOD berperan sebagai enzim antioksidan tubuh yang mengatasi radikal bebas (Silverthorn 2002). Pada kelompok pencegahan, Aktivitas SOD pada kelompok tikus yang diberikan diet kolesterol $1 \%$ selama 28 hari lebih rendah dibandingkan dengan kelompok tikus yang diberikan 
diet kolesterol $1 \%$ dengan penambahan ekstrak kulit pisang kepok. Hal ini diduga karena pada kelompok yang tidak dicekok ekstrak kulit pisang kepok, tubuh tikus menggunakan antioksidan endogen (SOD) untuk mengatasi radikal bebas yang dihasilkan pada oksidasi LDL, sedangkan pada kelompok yang dicekok ekstrak kulit pisang kepok, tubuh tikus menggunakan antioksidan eksogen flavonoid yang terkandung pada ekstrak untuk mengatasi radikal bebas sehingga SOD endogen di dalam tubuh dapat disimpan dan dihemat pemakaiannya. Flavonoid menetralkan radikal bebas dengan cara delokalisasi elektron. Struktur pada gugus flavonoid memberikan stabilitas yang tinggi pada radikal bebas melalui ikatan hidrogen (Zeka et al. 2017).

MDA merupakan produk akhir dari lipid peroksidasi yang digunakan sebagai biomarker biologis terjadinya stres oksidatif (Yuniastuti dan Iswari, 2015). Kadar MDA kelompok pencegahan yang diberikan diet kolesterol tanpa cekok ekstrak kulit pisang kepok lebih tinggi dibandingkan dengan kadar MDA kelompok yang dicekok ekstrak kulit pisang kepok. Kadar MDA yang tinggi menunjukkan bahwa jumlah radikal bebas dalam tubuh tikus tersebut lebih tinggi dibandingkan dengan kelompok yang dicekok ekstrak (Wresdiyati et al. 2007). Pemberian kolesterol sebanyak $1 \%$ selama 28 hari mengakibatkan peningkatan kolesterol plasma dan jaringan (Wresdiyati et al. 2006). Kondisi kolesterol yang tinggi dan penambahan konsumsi kolesterol secara terus menerus mengakibatkan kandungan LDL dalam darah meningkat. Kelebihan kolesterol digunakan oleh tubuh untuk membentuk garam empedu. Peristiwa ini menjadi rantai reaksi yang berkelanjutan karena garam empedu yang diekskresikan pada usus semakin banyak, sementara kolesterol terus ditambahkan (Silverthorn 2002). Jumlah radikal bebas yang dihasilkan lebih banyak dibandingkan dengan antioksidan di dalam tubuh sehingga mengakibatkan kondisi stress oksidatif. Reaksi peroksidasi lipid menghasilkan senyawa MDA yang jumlahnya semakin bertambah seiring dengan peningkatan peroksidasi lipid di dalam tubuh (Yuniastuti dan Iswari 2015).

Pada kelompok pengobatan, saat tikus telah mencapai kondisi hiperkolesterolemia, tubuh masih melangsungkan proses homeostasis untuk menyeimbangkan kadar kolesterol di dalam darah (Silvertorn 2002). Organ hati kelompok tikus yang dicekok ekstrak kulit pisang kepok setelah mencapai kondisi hiperkolesterolemia menunjukkan aktivitas SOD lebih tinggi dibandingkan dengan tikus tanpa cekok ekstrak setelah mencapai kondisi hiperkolesterolemia. Hal ini diduga karena antioksidan flavonoid yang terkandung di dalam ekstrak membantu mengatasi radikal bebas di dalam tubuh. Kelompok tikus tanpa cekok ekstrak kulit pisang kepok hanya menggunakan aktivitas antioksidan endogen untuk mengatasi radikal bebas yang telah terbentuk. Radikal bebas secara alami di netralkan oleh antioksidan endogen di dalam tubuh, namun penambahan antioksidan eksogen menjadi pengobatan yang efektif pada kondisi stress oksidatif (Csonka et al. 2016).

Kadar MDA pada kelompok pengobatan yang dicekok ekstrak kulit pisang kepok lebih rendah dibandingkan dengan kadar MDA kelompok tikus tanpa cekok ekstrak. Hal ini diduga karena senyawa flavonoid yang terkandung pada ekstrak kulit pisang kepok membantu mengurangi stress oksidatif pada tubuh tikus sehingga MDA yang dihasilkan oleh tubuh berkurang. Flavonoid juga bekerja mengurangi kadar kolesterol darah melalui penghambatan sintesis kolesterol. Hambatan sintesis kolesterol tersebut berada pada mekanisme penghambatan HMG KoA reduktase. Flavonoid berkompetisi dengan HMG KoA untuk berikatan dengan enzim HMG KoA reduktase. HMG KoA reduktase yang berikatan dengan flavonoid menyebabkan pembentukan asam mevalonat terhenti sehingga kolesterol tidak dapat disintesis. Flavonoid juga bekerja meningkatkan ekspresi reseptor LDL sehingga tingkat oksidatif LDL akan menurun (Zeka et al. 2017).

Berdasarkan hasil penelitian dapat disimpulkan bahwa ekstrak kulit pisang kepok dengan pelarut etanol $70 \%$ menunjukkan aktivitas antioksidan yang paling tinggi dibandingkan dengan jenis ekstrak lainnya. Ekstrak kulit pisang kepok dengan pelarut etanol 70\% dapat digunakan untuk menaikkan aktivitas SOD dan menurukan kadar MDA organ hati tikus model pencegahan dan pengobatan hiperkolesterolemia.

\section{UCAPAN TERIMA KASIH}

Studi dan penelitian ini dibiayai dari beasiswa kementerian keuangan melalui program Beasiswa Pendidikan Lembaga Pengembangan Dana Pendidikan (LPDP) Tahun 2016.

"Penulis menyatakan tidak ada konflik kepentingan dengan pihak-pihak yang terkait dalam penelitian ini". 


\section{DAFTAR PUSTAKA}

Choundary GP. 2013. Hypocholesterolemic effect of ethanolic extract of fruits of terminalia chebula in high fat diet fed foster rats. International Journal of Advances in Pharmacy, Biology and Chemistry. 2(1): 13-15.

Csonka C, Sarkozy M, Pipicz M, Dux L, Csont T. 2016. Modulation of hypercholesterolemia-induced oxidative/nitrative stress in the heart. Hindawi Publishing Corporation Oxidative Medicine and Cellular Longevity.

Enein AMA, Salama ZA, Gaafar AA, Aly HF, Elella FAB, Ahmed HA. 2016. Identification of phenolic compound from banana peel Musa paradisiacal $L$ as antioxidant and antimicrobial agents. JOCPR. 8(4): 46-55

Fatemeh SR, Ramli S, Al-Kharki AFM, Easa AM. 2012. Total phenolics, flavonoids and antioxidant activity of banana pulp and peel flours: influence of variety and stage of ripeness. International Food Research Journal. 19(3): 1041-1046.

Hasanah Q, Hasim, Faridah DN, Andrianto D. 2016. Inhibition activity of hmg-coa reduktase by rice brain extract and its fractions as anticholesterolemia in vitro study. Der Pharma Chemica. 8(23): 1-5.

Jim EL. 2013. Metabolisme protein. Jurnal Biomedik (JBM). 5(3): 149-156.

Maskar DH, Hardinsyah, Damayanti E, Astawan M, Wresdiyati T, Hermanianto J, Winandita T. 2015. Pengaruh kedelai produk rekayasa genetik terhadap kadarmalonaldehid, aktivitas superoksida dismutase dan profil darahpada tikus percobaan. Penelitian Gizi dan Makanan. 38 (1): 41-50

Nugroho KB, Sari DI, Ni'mah M. 2016. Potensi agaragar berbahan kulit pisang Mauli (Musa Sp. AA) khas Kalimantan Selatan sebagai antihiperlipidemia. Jurnal Pharmascience. 3(1): 56 - 65.

Pontang GS, Johan A, Subagio HW. 2014. Efek pemberian chlorophyllin terhadap kadar nitric oxide dan malondialdehida tikus hiperkolesterolemia. Jurnal Gizi Indonesia. 3(1): 26-31.

Santoso U. 2017. Antioksidan Pangan. Gadjah Mada University Press. Yogyakarta

Sayuti K, Yenrina R. 2015. Antioksidan Alami dan Sintetik. Padang (ID): Andalas University Press.
Suarsana IN, Wresdiyati T, Suprayogi A. 2013. Respon stress oksidatif dan pemberian isovlafon terhadap aktivitas enzim superoksida dismutase dan peroksidasi lipid pada hati tikus. JITV. 18(2): 146-152.

Silverthorn DU. 2002. Fisiologi Manusia. Jakarta (ID): Penerbit Buku Kedokteran EGC.

Steel RGD, Torrie JH. 1980. Principles and Procedures of Statistics. 2nd ed. New York: McGraw-Hill.

Wardati F. 2017. Potensi Ekstrak Kulit Pisang Kepok (Musa Balbisiana) Sebagai Kandidat Terapetik Kanker Payudara Secara In Vitro dengan Menggunakan Sel T-47D. UIN Maulana Malik Ibrahim. Malang.

White PAS, Oliveira RCM, Oliveira AP, Serafini $M R$, Araujo AAS, Gelain DP, Moreira JCF, Almeida JRGS, Quintans JSS, Qouintans-junior LJ, Santos MRV. 2014. Antioxidant activity and mechanisms of action of natural compounds isolated from lichens: a systematic review. Molecules. 19: 14496-14527.

Widyawati PS, Budianta TDW, Kusuma FA, Wijaya EL. 2014. Difference of solvent polarity to phytocemichal content and antioxidant activity of pluchea indicia less leaves extracts. IJPPR. 6(4): 850-855.

Wresdiyati T, Astawan M, Nurwati VD. 2006. Level antioksidan superoksida dismutase (SOD) menurun pada jaringan ginjal tikus hiperkolesterolemia: suatu kajian imunohistokimia. J. Sain Vet. 24(2): 168-176.

Wresdiyati T, Astawan M, Fithriani D, Adnyane IK, Novelina S, Aryani S. 2007. Pengaruh a-tokoferol terhadap profil superoksida dismutase dan malondialdehida pada jaringan hati tikus di bawah kondisi stres. Jurnal Veteriner. 202-209.

Yani M. 2015. Mengendalikan kadar kolesterol pada hiperkolesterolemia. Jurnal Olahraga Prestasi. 11(2): 1-7.

Young IS, Woodside JV. 2001. Antioxidants in health and disease. Journal Clinical Pathology. 54: 176-186.

Yuniastuti A, Iswari RS. 2015. Pengaruh suplementasi madu kelengkeng terhadap kadar tsa dan mda tikus putih yang diinduksi timbal (Pb). Jurnal MIPA. 38 (2): 108-114.

Zeka K, Ruparelia K, Arroo RRJ, Budriesi R, Micucci M. 2017. Flavonoids and their metabolites: prevention in cardiovascular diseases and diabetes. Disease. 5:19 